\title{
STUDENT LEARNING ACTIVITIES USING REALISTIC MATHEMATICS EDUCATION (RME)
}

\author{
Mega Ratrisna Dyah Ayu Pamungkas ${ }^{1}$, Abdul Taram ${ }^{2}$ \\ ${ }^{1,2}$ Universitas Ahmad Dahlan, Yogyakarta \\ megaratrisna27@gmail.com ${ }^{1}$, taramabdul@gmail.com²
}

\begin{abstract}
ABSTRAK
Tujuan penelitian ini adalah untuk meningkatkan aktivitas siswa dalam pembelajaran matematika dengan menggunakan Realistic Mathematics Education (RME) di kelas VIII SMP Muhammadiyah 2 Prambanan. Penelitian dilakukan dua siklus. Teknik pengumpulan data yang digunakan adalah observasi, wawancara, dokumentasi dan triangulasi. Lembar observasi penelitian instrumen dan wawancara. Analisis instrumen menggunakan validitas isi. Analisis yang digunakan adalah deskriptif kualitatif. Hasil penelitian menunjukkan bahwa Realistic Mathematics Education (RME) dapat meningkatkan aktivitas belajar siswa Hal ini terbukti dari pengamatan aktivitas siswa dalam pembelajaran setiap siklus mengalami peningkatan, yaitu rata-rata persentase observasi aktivitas siswa pada siklus I 50,623\% (cukup), dan pada siklus II meningkat menjadi $61.960 \%$ (baik). Dari hasil wawancara dengan siswa menunjukkan respon positif terhadap aktivitas belajar siswa.
\end{abstract}

Kata kunci: realistis, RME, pembelajaran aktivitas siswa

\begin{abstract}
The aims of this research is to increase student activity in learning mathematics by using Realistic Mathematics Education (RME) in class VIII SMP Muhammadiyah 2 Prambanan. The study was conducted two siklus. Data collection techniques used are observation, interview, documentation and triangulation. Instrument research observation sheet and interview. Instrument analysis using content validity. The analysis used is descriptive qualitative. The results showed that Realistic Mathematics Education (RME) can increase student learning activity This is evident from the observation of student activity in learning every siklus has increased, that is average of observation percentage of student activity in siklus I 50,623\% (enough), and at siklus II increased to $61.960 \%$ (good). From the results of interviews with students showed a positive response on student learning activity.
\end{abstract}

Keywords: realistic, RME, student activity learning

\section{INTRODUCTION}

Education is the most important component in the development of the nation and state because the nation that is prosessing and succesding is a nation that is able to educate the life of its people (Aisyah : 2015). Learning is an important activity that everyone must do to the maximal to master or gain something. (syarifudin: 2011). Learners are said to learn when there is a change in the affective, cognitive, and psychomotor aspects in themselves as a learning experience (Kurniawan, Nining: 2006). 
The proces of implementation of mathematics learning in school often experence obstacles, one of them low student activity hence requires effort of teacher in increasing student avtivity in teaching and learining procces (Adhia : 2015). Activity is a principleor priciple that very important in the interaction of teaching and learning (Kenan : 2014). Student activity in learning process is very important because learning not only transfer knowledge from teacher to student but also create situation which can bring active and creative student learn to achieve behavioral change (Raharjo : 2014). Activity is activity, liveliness ada busyness mathematics (Tarigan : 2014).

Realistic Mathematics Education is an approach that emphasizes the conceptualisation of teaching and has the tendency of learners to be active in the learning process (Adila: 2016). Realistic mathematics learning is basically the utilization of reality and the environment that learners understand to expedite the process of learning mathematics, so as to achieve the goal of mathematics education better than the past (Sulistiowati: 2011). Realistic Mathematics Education also emphasizes to bring mathematics to meaningful teaching by relating it in realistic daily life (Muklis: 2012) This means that mathematics is not a ready subject for learners, but that mathematics is a dynamic lesson that can be learned by doing it (Muhtadi \& Sukirwan: 2017). The characteristics of the approach are (1) students are more actively thinking (2) context and teaching materials related to the environment and learners (3) the role of teachers is more active in designing teaching materials and class activities (Sembiring: 2010).

Therefore, to improve the activity and learnig outcomes of student on mathematics subject. Teacher should be able to create in optimal learnif environment by applying an appropriate and anjoyable learning appoarch. Realistic Mathematics Education learning that allegendly can increase student learning activity beacause this appoach us focused on the activity of student the learnibg process so that students can easily understand ad present the teaching mathematics in the classroom 


\section{RESEARCH METHOD}

This research is Classroom Action Research. The subject of this research is the students of class VIII SMP Muhammadiyah 2 Prambanan semester of the academic year 2015/2016 which amounted to 27 students. This research was conducted in SMP Muhammadiyah 2 Prambanan. Objects studied in this research is the implementation of the process and the results obtained from the realistic mathematics education in learning mathematics as an effort to improve the learning activities of students of class VIII SMP Muhammadiyah 2 Prambanan. The research procedure used in this PTK consists of three siklus. Learning at the stage of siklus I, siklus II and siklus III by using a realistic mathematics education. activities carried out during each cycle are as follows (1) planning, (2) implementation of action, (3) observation and (4) reflection.

Data collection techniques used in this study were as follows: (1) interviews were conducted on several students at the end of each cycle meeting, (2) observation was conducted to determine student learning activities during the learning process, (3) triangulation is defined as data collection techniques combining from various data collection techniques and data sources that already exist.

The indicator of success of this research is student learning activity in learning mathematics increase, that is if activity of student at least reach good criterion that is $>60 \%$.

\section{RESULTS AND DISCUSSIONS}

Material: geometry flat side (cube and cuboid). Students are divided into six groups. Students make cage nets and beams of paper that have been provided. Students find the formula of the surface area of the cube and the cuboid of the webs that students make. Learning that has been done thoroughly in the action of cycle I and cycle II through the approach of realistic mathematics learning shows that there is an increase in student learning activities on the subject of building a flat side space.Aspects studied are student learning activities that include 1) student enthusiasm in learning. 2) student interaction with teacher 3) interaction 
among learners 4) group cooperation 5) student activity in group 6) student participation concluded result of discussion.

From the data obtained shows that students as much as $50.623 \%$ active in learning activities. The number is not maximal because from the observation there are still students who have not cooperated with each other in the group, the interaction between students is still lacking and the discussion of group activities and class discussions to participate concluded the discussion is still lacking. This is due to the lack of guidance of teachers in carrying out learning activities. After a reflection of improvement in teaching and learning process.

In the siklus II there is an increase in the percentage of student learning activities to $60.96 \%$ active students in learning activities. This number has met the desired research criteria that is above $60.00 \%$. Student and teacher response to mathematics learning using realistic mathematical approach is very good. This can be seen from the results of interview researchers with some students and teachers of grade VIII mathematics.

Based on the predetermined success of the research, the research has been successful. The provisions of success states that research succeeds if student learning activities reach more than $60 \%$, meanwhile after doing this second cycle obtained student learning activity reach $60,96 \%$.

It means that the learning activity of the students has exceeded the determination of the success of this research.

\section{CONCLUSION}

Based on the results of classroom action research can be concluded that there is an increase in mathematics learning activities of students of grade VIII SMP Muhmmadiyah 2 Prambanan semester of the academic year 2015/2016. This can be seen from the indicators as follows: There is an increase in student learning activities in the learning process of mathematics. Based on observation data there is an increase of the average percentage of student learning activities in each siklus that is equal to $50.623 \%$ (enough) in the first siklus increased to $61.96 \%$ (good) in siklud II. Mathematical learning using Realistic Mathematics Approach get positive response from students which means students can receive well and are 
interested in following the learning by using Realistic Mathematics Education. This is evident from the results of interviews with students who showed the learning went smoothly and received a positive response.

\section{REFFERENCE}

Adhia, Hana. 2015. Peningkatan Aktivitas Belajar Matematika Siswa Kelas XII TKR SMK Adzkia Padang Dengan Model STAD. Jurnal LEMMA Volume 2, Nomor 2, November 2015.

Aisyah, Siti. 2015. Meningkatkan Aktivitas Belajar Siswa dengan Menerapkan Kolaborasi Pembelajaran Kolaboratif. Jurnal Pendidikan Bisnis dan Managemen Volume 1, Nomor 1, Juli 2015.

Aldila, Ekasatya. 2016. Makna Realistic dalam PMRI dan RME. Jurnal LEMMA Volume 2, Nomor 2, Maret 2016, ISSN: 96 - 104

Kenan. 2014. Upaya Peningkatan Aktivitas Belajar Siswa Melalui Penerapan Metode Penguasaan Pada Materi Pokok Menulis Di Kelas IV SD Negeri 0506-49 Simpang Pulau Rambung. Jurnal Saintech Volume 6, Nomor 2, Juni 2014, ISSN: 2086-9681.

Kurniawan, Fajar \& Nining. 2016. Analisis Lembar Kerja Siswa Mata Pelajaran Matematika Ditinjau Dai Taksonomi Bloom Revisi. Publikasi Ilmiah. Universitas Muhammadiyah surakarta : Surakarta.

Muchlis, Effie Efrida. 2012. Pengaruh Pendekatan Pendidikan Matematika Realistik Indonesia (PMRI) Terhadap Perkembangan Kemampuan Pemecahan Masalah Siswa Kelas II di SD Kartika 1.10 Padang. Jurnal Exacta Volume 5, Nomor 2, Desember 2012, ISSN: 1412 - 3617.

Muhtadi, Dedi \& Sukirman. 2017. Implementasi PMRI Untuk Meningkatkan Kemampuan Berfikir Kreatif Matematik Dan Kemandirian Belajar Paserta Didik. Jurnal Mosharafa Volume 6, Nomor 1, Januari 2017, pISSN: 2086-4280, e-ISSN: 2527-8827.

Raharjo, Joko. 2014. Peningkatan Aktivitas Belajar Matematika dengan Penerapan Metode Problem Posing Tipe Post Solution Posing. Naskah Publikasi. Universitas Muhammadiyah Surakarta : Surakarta.

Sembiring, Robert. 2010. Pendidikan Matematika Realistik Indonesia (PMRI) : Perkembangan Dan Tantanganya.Jurnal IndoMS. J.M.E Volume 1, Nomor 1, juli 2010, pp.11-16.

Sulistiowati, Evi. 2011. Pendekatan Matematika Realistik Untuk Meningkatkan Kemampuan Berfikir Siswa Ditingkat Sekolah Dasar. Jurnal Edisi Khusus Nomor 2, Agustus 2011, ISSN: 1412-565X

Syarifuddin, Ahmad. 2011. Penerapan Model Pembelajaran Cooperative Belajar Dan Faktor-Faktor Yang Mempengaruhi. Jurnal Ta'dib Volume 16, Nomor 1, Juni 2011.

Tarigan, Daitin. 2014. Meningkatkan Aktivitas Belajar Siswa Dengan Menggunakan Model Make A Match Pada Mata Pelajaran Matematika Di Kelas V SDN 050687 Sawit Seberang. Jurnal Kreano Volume 5, Nomor 2, Juni 2014, ISSN: 2086-2334. 